\title{
Chemical and Physical Characteristics in Uncultivated Soils with Different Lithology in Semiarid Mediterranean Clima
}

\author{
Daniel Moraetis, ${ }^{1}$ Nikolaos Lydakis-Simantiris, ${ }^{2}$ Despina Pentari, ${ }^{3}$ \\ Emmanouil Manoutsoglou, ${ }^{3}$ Chryssa Apostolaki, ${ }^{3}$ and Vasilios Perdikatsis ${ }^{3}$ \\ ${ }^{1}$ Earth Science Department, Sultan Qaboos University, College of Science, 123 Muscat, Oman \\ ${ }^{2}$ Department of Natural Resources and the Environment, Technological and Educational Institute of Crete, 73133 Chania, Greece \\ ${ }^{3}$ School of Mineral Resources Engineering, Technical University of Crete, 73100 Chania, Greece \\ Correspondence should be addressed to Despina Pentari; pentari@mred.tuc.gr
}

Received 30 October 2015; Accepted 6 April 2016

Academic Editor: Francesco Sdao

Copyright (C) 2016 Daniel Moraetis et al. This is an open access article distributed under the Creative Commons Attribution License, which permits unrestricted use, distribution, and reproduction in any medium, provided the original work is properly cited.

\begin{abstract}
The aim of this study is to identify the chemical and physical characteristics in uncultivated soils derived from different parent materials under semiarid Mediterranean climatic conditions which favoured the formation of fragile soils. The current work is of great interest in the agriculture and environmental stakeholders for providing a "benchmark" of undisturbed soil quality regarding organic content and nutrients availability. Principal Component Analysis (PCA) was used as the primary tool to demonstrate the soil quality stage, regarding nutrient availability. The statistical analysis revealed that one of the major physicochemical characteristics such as cation exchange capacity (CEC) is controlled exclusively from mineralogy and not from organic matter. Mineralogy and bulk chemical analysis is directly related to soil parent material lithology. The availability of inorganic nutrients (macro- and micronutrients) is low and relatively identical to most of the soils. PCA shows the unusual correlation of $\mathrm{K}^{+}$with not only illite content but also the OM in soils. The development of soils which are already of low quality in respect of organic content and nutrients is evident in Crete in most of the 54 samples investigated.
\end{abstract}

\section{Introduction}

Soil is the dynamic link between the biosphere and lithosphere and constitutes a practically not renewable (very low rate of formation) natural resource, with a key role for the environment and for the agriculture. It is a key component of the Earth System since it controls the hydrological, ecological, biological, and geochemical cycles [1-5]. The properties that are critical for soil quality (i.e., nutrients content, $\mathrm{pH}$, and electrical conductivity) are governed by climatic, biological, and geological factors [6-9]. Mineral weathering is an important source of inorganic nutrients in soils under natural conditions [10]. Geologic gradient affects severely nutrient pools in soils [10]. Areas underlain by serpentinite or generally ultramafic rocks are rich in $\mathrm{Mg}, \mathrm{Fe}, \mathrm{Ni}$, and $\mathrm{Cr}$ and depleted in $\mathrm{K}, \mathrm{Ca}, \mathrm{P}$, and $\mathrm{Zn}$ [11]. On the other hand, soils developed in volcanic ash exhibit high cation exchange capacity (CEC) [12]. Hepper et al. [13] stated that CEC was controlled mainly by clay content in ash rich soils and by organic matter $(\mathrm{OM})$ in ash free soils.

Apart from nutrients release through weathering processes, soil characteristics are further affected by atmospheric deposition, drainage outflow, biomass removal, and other processes such as cation exchange and organic matter decomposition, while pronounced interrelations exist between all factors mentioned above [7].

High geologic variability mainly appeared in tectonically active areas like boundaries of orogenetic belts. Crete is situated in the external plate of the Eurasian plate and exhibits a large variety of geomorphic and geologic features. So far, a number of papers have been published concerning soil taxonomy in Greece (i.e., [14, 15]). The geological framework of Crete has been studied thoroughly [16-18] and soil development appears mainly in limestones, ultramafic rocks, calcareous marls, metamorphic rocks (phyllites-quartzites), and alluvial sediments. Moreover, Crete exhibits a semiarid 
Mediterranean climate (long hot-summers $20-31^{\circ} \mathrm{C}$ ) which remained unchanged the last $20 \mathrm{Ma}$ (late Miocene-early Pliocene till present) [19]. Thus, soils appear relatively fragile with low organic content, sparse vegetation, and being prone to desertification $[20,21]$. The last decade a major concern has been raised regarding the preservation of our soils and that it is mentioned also in the recent accomplished European funded project Soil Transformation in European Catchments (SoilTrEC) [22]. Climate change has been reported as a severe driving force for soil deterioration in areas such as England and Wales [23-27]. Crete will also be affected by climate change and represents an area of high desertification risk. Although many studies on the soil degradation have been published for Mediterranean countries, very few are reporting the current state of uncultivated and undisturbed soils [28-30]. The reason behind it is that very few places in Europe are still intact of manmade activities. Many soil modeling studies specifically for carbon sequestration and/ or erosion are missing data for undisturbed soils (initial conditions) ([31] and references therein and [32]). The lack of data is magnified when the soil lithology variability is considered. Crete still preserves several places of undisturbed soil development over different lithologies. Such areas could be used as a benchmark against which the soil manmade impact and the future climatic changes could be further quantified.

The present study aims to identify physical and chemical characteristics in undisturbed soils of different lithology of parent rock with sparse vegetation under the influence of Mediterranean climatic conditions. We aim to clearly demonstrate the fragile nature of soils from Crete for uncultivated areas with low organic content and to supply data that are important for assessing thin soils in semiarid climates. For this reason, soil samples from uncultivated areas of different bedrocks were collected and their mineralogical characteristics, physical and chemical properties, and their nutrient content were investigated. Principal Component Analysis (PCA) was applied on chemical and physical characteristics of all samples in order to identify groups of samples with common characteristics and to investigate and to rationalize the potential correlations among soil characteristics.

\section{Materials and Methods}

2.1. Geological Outline. The samples were collected from six areas in the island of Crete with four different bedrock lithologies. The different bedrocks are alluvial sediments (quaternary sediments) from two plateaus, ultramafic rocks, quartzite-phyllite rocks, and Neocene marly limestones. Mesozoic limestones were excluded since they are mainly situated in high altitudes with limited soil profiles. The aforementioned lithologies are present at Omalos Plateau $(\mathrm{O})$ in western Crete, Lasithi Plateau in East Crete (La), Anogia in central Crete (U), Kantanos (Ka) and Kantanos-Kountoura $(\mathrm{Kb})$ in western Crete, and Platanos (PL) in west Crete (Figure 1). The areas exhibit generally thin soil development.

Omalos area is situated in the west part of "Lefka Ori" mountains and its geomorphology is a typical plateau $(1050 \mathrm{~m}$ elevation). The rock formations around the Omalos Plateau are mainly part of the Trypali limestones and less of the Plattenkalk limestones with minor outcrops of phyllitesquartzites series, whereas quaternary sediments have filled the plateau [16-18, 33]. The soil samples were collected from areas where the soil overlaid the quaternary formations (alluvial) within the plateau.

Lasithi soils were collected from Lasithi Plateau (353 m), which shows similar geological setting to Omalos Plateau. Limestones, mainly of Plattenkalk nappe and phyllitesquartzite group, are situated in the surrounding area of the plateau, whereas the soil samples were collected from the top of alluvial deposits.

Anogia area is underlain by ophiolites (mainly ultramafic rocks: peridotites). The most extended ophiolite outcrop in Crete exists in the area of Anogia village (701 m elevation). The ultramafic rocks comprise predominantly serpentinized peridotites. The overlying soil is mainly of limited thickness, whereas in land depressions and cavities the soil layer appears much thicker.

The parent rock of Kantanos area comprises metamorphic quartzite-phyllite group. Quartzite group in west Crete facies belt is characterized by an alternation of metagreywackes, meta-sandstones, and metapelites [34, 35]. Two different sets of soil samples were collected from Kantanos area $(\mathrm{Ka})$ and Kantanos-Kountoura area $(\mathrm{Kb})$ (both around $350 \mathrm{~m}$ elevation). The former soil is developed in eroded quartzite-phyllite group rich in quartz, whereas the latter is developed in phyllite-quartzite group with less quartz and higher mica content.

Platanos area comprises mainly of Neocene marls with intercalations of limestones and sandstones. The area is situated in the most western part of Crete compared to the other sampling sites (Figure 1) and elevation is $250 \mathrm{~m}$.

2.2. Sample Collection and Pretreatment. Sampling was carried out using a special soil auger, designed for all soil types, and samples were collected from the top $20 \mathrm{~cm} .54$ samples were collected from sites chosen according to three strategic guidelines: (i) sites with uncultivated in situ soils (covered rarely by shrubs), (ii) sites where the mineralogical variation was apparent due to different parent materials, and (iii) sites with varied precipitation due to orientation (eastwest). Samples were taken from six different areas, as follows (Figure 1): Omalos Plateau, nine samples (O1-O9); Kantanos, seven samples (Ka1-Ka7); Kantanos-Kountoura, eleven samples (Kb1-Kb11); Anogia, eight samples (U1-U8); Lasithi, eleven samples (La1-La11); and Platanos, eight samples (PL1PL8). Samples were transferred to the laboratory, dried at $37^{\circ} \mathrm{C}$ for $48 \mathrm{~h}$, and subsequently sieved through the $2 \mathrm{~mm}$ sieve.

2.3. Mineralogical Analysis. Mineralogical composition was determined by X-ray diffraction (XRD) technique using a Siemens D500 powder diffractometer, on two grain fractions, silt $(<63 \mu \mathrm{m})$ and clay $(<2 \mu \mathrm{m})$. These fractions were attained by separation with an Atterberg cylinder [36]. The data were obtained at $35 \mathrm{kV}$ and $35 \mathrm{~mA}$, with a graphite monochromator, using $\mathrm{CuKa}$ radiation. A $0.03^{\circ}$ scanning step and 2-s scanning time per step were used for the range 


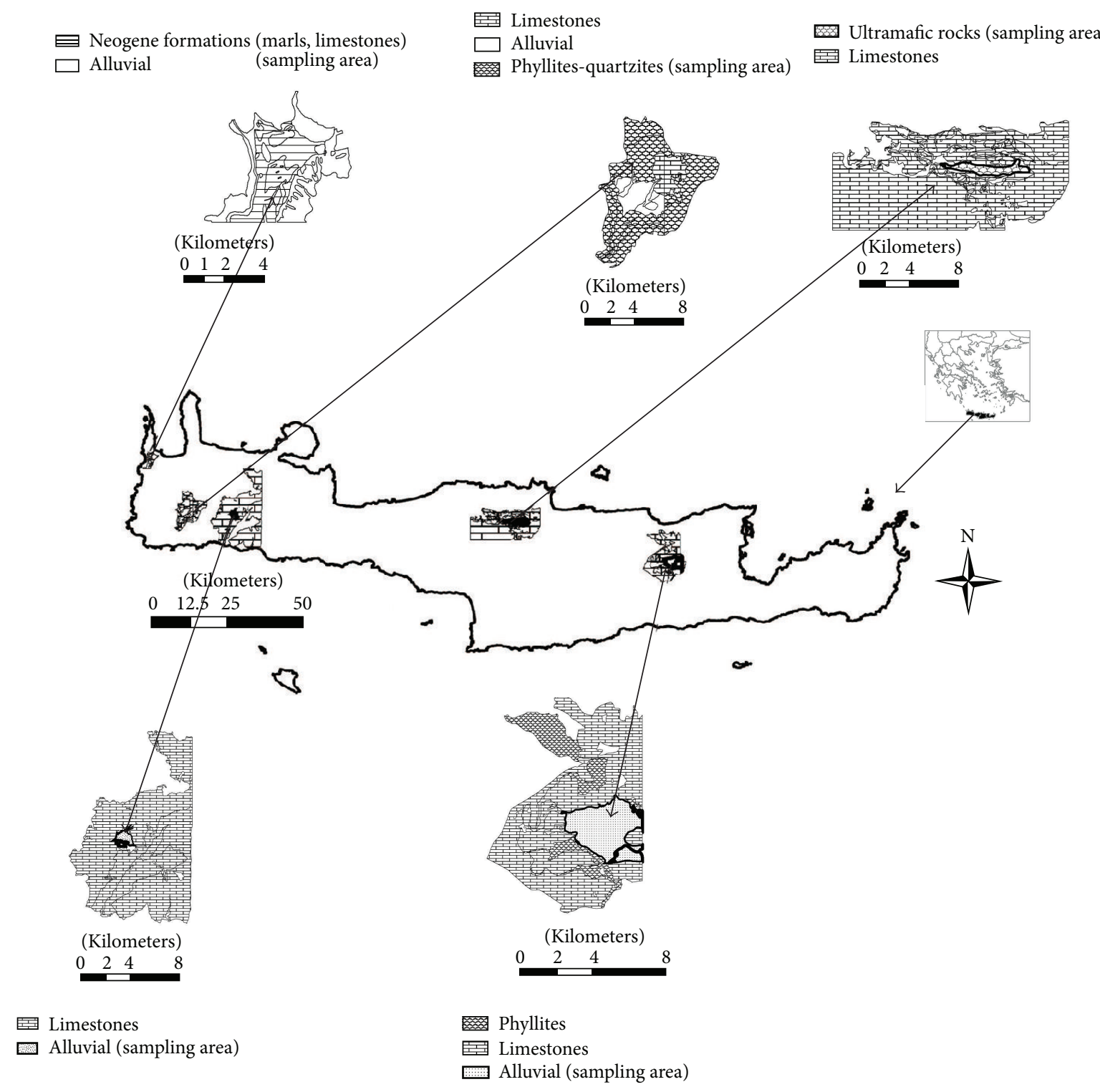

FIgURE 1: Geological outline in the sampling areas.

3 to $70^{\circ}$. The qualitative evaluation of the data was done with the Software Diffrac Plus (SOCABIM SAS France). The quantitative analysis was carried out by the Rietveld Method.

\subsection{Chemical Analyses on Soils and Extraction Solutions.} The bulk chemical analysis of the samples was carried out by X-ray fluorescence spectroscopy (S2 Ranger, Bruker EDS $\mathrm{XRF}$ ), on the less than $2 \mathrm{~mm}$ sample fraction. Measurements were carried out at $40 \mathrm{kV}$ with an $\mathrm{Al}$ filter $(500 \mu \mathrm{m})$ for the heavier elements $(\mathrm{Fe}, \mathrm{Mn}, \mathrm{Ti}, \mathrm{Ca}$, and $\mathrm{K})$ and at $20 \mathrm{kV}$ for the lighter elements $(\mathrm{P}, \mathrm{Si}, \mathrm{Al}, \mathrm{Mg}$, and $\mathrm{Na}$ ) without the use of filter. $\mathrm{pH}$ was determined in the supernatant of a soil: water mixture 1:2, according to Thomas [37] by a $\mathrm{pH}$ meter (WTW, 340i). Electrical conductivity was determined by a conductivity electrode (WTW, 340i) in the extract from saturated soil pastes. Calcium content was determined in the same extract after filtration, by flame atomic absorption spectrometry (AAS) (Perkin Elmer, AA100). Available $\mathrm{K}^{+}$ and $\mathrm{Mg}^{2+}$ were extracted from soil samples by agitation in $1 \mathrm{M} \mathrm{CH}_{3} \mathrm{COONH}_{4} \mathrm{pH} 7$ solution $[38,39]$ and determined by AAS. Available micronutrients $\mathrm{Fe}^{2+}, \mathrm{Cu}^{2+}, \mathrm{Mn}^{2+}$, and $\mathrm{Zn}^{2+}$ were extracted from the soil samples by the DTPA method, at $\mathrm{pH} 7.3$ [40], and their concentrations were determined by AAS. Phosphorous extraction was carried out by a $0.5 \mathrm{M}$ sodium bicarbonate solution [41] and its concentration was measured photometrically at $882 \mathrm{~nm}$ ( $\mathrm{HACH}, \mathrm{DR} / 4000 \mathrm{U}$ ) using a standard calibration curve. Nitrates were extracted with $1 \mathrm{M} \mathrm{KCl}$ and $\mathrm{NO}_{3}-\mathrm{N}$ concentration was measured photometrically [42]. The concentration of organic matter was calculated according to Walkley and Black [43].

2.5. Cation Exchange Capacity-Grain Size Analysis. Cation exchange capacity (CEC) was determined by the method described by Sumner and Miller [44] modified for soils in arid regions. After the removal of $\mathrm{CaCO}_{3}$ with $\mathrm{HCl} 2 \mathrm{~N}$, soil 
TABLE 1: Mineralogical quantitative analysis mean values for $<63 \mu \mathrm{m}$ and $<2 \mu \mathrm{m}$ fractions.

\begin{tabular}{|c|c|c|c|c|c|c|c|c|c|c|c|c|}
\hline & \multicolumn{6}{|c|}{$<63 \mu \mathrm{m}(\%)$} & \multicolumn{6}{|c|}{$<2 \mu \mathrm{m}(\%)$} \\
\hline & $\mathrm{O}$ & $\mathrm{La}$ & $\mathrm{U}$ & $\mathrm{Ka}$ & $\mathrm{Kb}$ & $\mathrm{PL}$ & $\mathrm{O}$ & $\mathrm{La}$ & $\mathrm{U}$ & $\mathrm{Ka}$ & $\mathrm{Kb}$ & PL \\
\hline Calcite & 0.3 & - & - & - & - & 64.3 & - & - & - & - & - & 33.3 \\
\hline Dolomite & - & - & 2.9 & - & - & 1.9 & - & - & - & - & - & - \\
\hline Quartz & 67 & 58.2 & 9.7 & 27.4 & 22.7 & 13.2 & 4.5 & 4.4 & 2.2 & 3.1 & - & 5.3 \\
\hline Feldspars & - & 13.7 & - & 3.7 & 5.8 & 5 & - & - & - & 8.6 & - & - \\
\hline Illite & 12.1 & 17.6 & 1.3 & 33.3 & 33.2 & 15.5 & 55.8 & 60.8 & 2.8 & 23 & 71.6 & 43.5 \\
\hline Kaolinite & 20.6 & 3.2 & - & 26.5 & 26.8 & - & 39.7 & 18.9 & - & 63 & 14.8 & - \\
\hline Paragonite & - & - & 7.4 & 9.1 & 11.5 & - & - & - & - & 2.3 & 13.7 & - \\
\hline Chlorite & - & 7.4 & 21.2 & - & - & - & - & 15.9 & 46.4 & - & - & 6.5 \\
\hline Antigorite & - & - & 49.2 & - & - & - & - & - & 33.7 & - & - & - \\
\hline Talc & - & - & 8.3 & - & - & - & - & - & - & - & - & - \\
\hline Smectite & - & - & - & - & - & - & - & - & 14.8 & - & - & 11.4 \\
\hline
\end{tabular}

-: not determined.

TABLE 2: Mean concentrations for major elements content in soils (energy dispersive-XRF); measurement relative standard error was less than $5 \%$.

\begin{tabular}{|c|c|c|c|c|c|c|c|c|c|c|c|c|}
\hline Sample & $\begin{array}{c}\mathrm{Na}_{2} \mathrm{O} \\
(\%) \\
\end{array}$ & $\begin{array}{c}\mathrm{MgO} \\
(\%) \\
\end{array}$ & $\begin{array}{c}\mathrm{K}_{2} \mathrm{O} \\
(\%)\end{array}$ & $\begin{array}{c}\mathrm{CaO} \\
(\%)\end{array}$ & $\begin{array}{c}\mathrm{TiO}_{2} \\
(\%)\end{array}$ & $\begin{array}{c}\mathrm{MnO} \\
(\%)\end{array}$ & $\begin{array}{c}\mathrm{Fe}_{2} \mathrm{O}_{3} \\
(\%)\end{array}$ & $\begin{array}{c}\mathrm{Al}_{2} \mathrm{O}_{3} \\
(\%) \\
\end{array}$ & $\begin{array}{c}\mathrm{SiO}_{2} \\
(\%)\end{array}$ & $\begin{array}{c}\mathrm{P}_{2} \mathrm{O}_{5} \\
(\%) \\
\end{array}$ & $\begin{array}{c}\text { LOI } \\
(\%) \\
\end{array}$ & SUM \\
\hline $\mathrm{O}$ & 0.6 & 0.5 & 1.2 & 1.0 & 0.4 & 0.1 & 3.8 & 8.4 & 83.1 & $<0.05$ & 1.0 & 100.1 \\
\hline $\mathrm{La}$ & $<0.2$ & 3.8 & 1.7 & 0.9 & 0.6 & 0.2 & 6.2 & 23.3 & 61.6 & 0.4 & 1.6 & 100.1 \\
\hline $\mathrm{U}$ & $<0.2$ & 26.4 & 0.5 & 1.2 & 0.4 & 0.3 & 11.1 & 6.2 & 40.9 & $<0.05$ & 13.8 & 100.6 \\
\hline $\mathrm{Ka}$ & 1.5 & 0.5 & 1.6 & 0.02 & 0.8 & 0.04 & 4.9 & 14.2 & 72.1 & 0.1 & 4.2 & 99.9 \\
\hline $\mathrm{Kb}$ & 1.00 & $<0.2$ & 1.8 & 0.4 & 0.8 & 0.03 & 4.1 & 14.5 & 62.2 & $<0.05$ & 14.9 & 99.7 \\
\hline PL & $<0.2$ & 2.5 & 1.7 & 26.4 & - & 0.1 & 2.3 & 4.7 & 24.2 & - & 38.4 & 100.2 \\
\hline
\end{tabular}

-: not determined.

samples were saturated with $\mathrm{CaCl}_{2} 2 \mathrm{~N}$ and the adsorbed $\mathrm{Ca}^{2+}$ was extracted using $\mathrm{NaCl} 2 \mathrm{~N}$ solution [45]. Determination of $\mathrm{Ca}^{2+}$ in extracted solutions was carried out by AAS.

The content of sand, clay, and silt of the samples (grain size analysis) was determined with the Bouyoucos method [36].

\section{Results}

Results for the physical and chemical parameters of soils are presented separate for each area and then PCA analysis is applied for all samples and it is presented in a separate section. Lasithi and Omalos are presented together since they are both plateau areas and Kantanos and Kantanos-Kountoura data are also presented together since both are adjacent areas with seemingly the same soil parent material.

3.1. Omalos and Lasithi Plateaus. Omalos and Lasithi soils have been developed in plateau and the parent material is alluvial deposits as has already been mentioned. The soils have contrasting characteristics in mineralogy, in bulk chemical analysis and other physical and chemical parameters. The silt fractions $(<63 \mu \mathrm{m})$ of Omalos (O) soils exhibit higher quartz content compared to the Lasithi (La) soils and this is also reflected in the chemical analysis of the soils (Tables 1 and 2). Chlorite is present in the clay fraction $(<2 \mu \mathrm{m})$ for La soil samples, but it is absent in $\mathrm{O}$ samples. Illite and kaolinite are characteristic weathering products of feldspars which are present in the bedrocks. Calcite is only a minor phase in both areas despite the widespread limestone outcrops in the plateau surrounding area attributed to the ease of calcite dissolution (karstification). $\mathrm{O}$ soils contain higher kaolinite and less illite content compared to La soils.

Table 2 shows the chemical composition (XRF) of the soil samples. Omalos soils have higher $\mathrm{SiO}_{2}$ content $(83.1 \%)$ compared to other areas. Lasithi samples exhibit higher $\mathrm{MgO}$ content (3.79\%) compared to Omalos soils (0.47\%).

Average, minimum, maximum values, and standard deviation (due to spatial variability) of the physicochemical parameters measured for all soils are illustrated in Table 3. Lasithi soils have statistically the same $\mathrm{pH}$ (7.4) compared to Omalos soils (6.4) (Table 3). This is not the case with electrical conductivity values (O: $187, \mathrm{La}: 364 \mu \mathrm{S} / \mathrm{cm})$ and this is related to different availability of nutrients in the two areas. Lasithi soils exhibit on average higher availability of nutrients compared to Omalos soils (La: 114, 228, $38 \mathrm{mg} / \mathrm{kg}$, O: 50, 64, $5 \mathrm{mg} / \mathrm{kg}$, for $\mathrm{K}^{+}, \mathrm{Mg}^{2+}, \mathrm{Ca}^{2+}$, resp.); however, there is spatial variability for both sites which is expected in sedimentary basins such as in those plateaus.

Lasithi samples have higher CEC values (8.52 meq/ $100 \mathrm{gr})$, compared to Omalos soils CEC (4 meq/100 gr) (Table 3). Grain size analysis shows loam and silt loam fractions for O soils, whereas La soils are finer (mainly in clay loam fraction). 
TABLE 3: Average values in soils from investigated areas for $\mathrm{pH}$, electrical conductivity, $\mathrm{CEC}$, macronutrients $\left(\mathrm{Mg}^{2+}, \mathrm{Ca}^{2+}, \mathrm{K}^{+}, \mathrm{NO}_{3}{ }^{-}, \mathrm{PO}_{4}{ }^{3-}\right)$, micronutrients $\left(\mathrm{Cu}^{2+}, \mathrm{Mn}^{2+}, \mathrm{Fe}^{2+}, \mathrm{Zn}^{2+}\right)$, and organic matter $(\mathrm{OM})$. Standard deviation, minimum, and maximum are also presented. Identical letters in the same column denote no statistical difference in average values according to $t$-test with alpha coefficient $5 \%$.

\begin{tabular}{|c|c|c|c|c|c|c|c|c|c|c|c|c|c|}
\hline & $\mathrm{pH}$ & $\begin{array}{c}\mathrm{EC} \\
(\mu \mathrm{S} / \mathrm{cm})\end{array}$ & $\begin{array}{c}\text { CEC } \\
(\mathrm{meq} / 100 \mathrm{~g})\end{array}$ & $\begin{array}{c}\mathrm{K}^{+} \\
(\mathrm{mg} / \mathrm{kg})\end{array}$ & $\begin{array}{c}\mathrm{Mg}^{2+} \\
(\mathrm{mg} / \mathrm{kg})\end{array}$ & $\begin{array}{c}\mathrm{Ca}^{2+} \\
(\mathrm{mg} / \mathrm{kg})\end{array}$ & $\begin{array}{c}\mathrm{Cu}^{2+} \\
(\mathrm{mg} / \mathrm{kg})\end{array}$ & $\begin{array}{c}\mathrm{Mn}^{2+} \\
(\mathrm{mg} / \mathrm{kg})\end{array}$ & $\begin{array}{c}\mathrm{Fe}^{2+} \\
(\mathrm{mg} / \mathrm{kg})\end{array}$ & $\begin{array}{c}\mathrm{Zn}^{2+} \\
(\mathrm{mg} / \mathrm{kg})\end{array}$ & $\begin{array}{l}\mathrm{P}^{-} \mathrm{PO}_{4}{ }^{3-} \\
(\mathrm{mg} / \mathrm{kg})\end{array}$ & $\begin{array}{l}\mathrm{N}^{-\mathrm{NO}_{3}}{ }^{-} \\
(\mathrm{mg} / \mathrm{kg})\end{array}$ & OM\% \\
\hline \multicolumn{14}{|c|}{ O (9 samples) } \\
\hline Average & $6.4^{\mathrm{ba}}$ & $187^{\mathrm{a}}$ & $4^{\mathrm{a}}$ & $50^{\mathrm{b}}$ & $64^{\mathrm{a}}$ & $5^{\mathrm{a}}$ & $0.5^{\mathrm{a}}$ & $10^{\mathrm{a}}$ & $6^{\mathrm{a}}$ & $0.3^{\mathrm{a}}$ & $1.1^{\mathrm{ab}}$ & $2.6^{\mathrm{a}}$ & $0.64^{\mathrm{c}}$ \\
\hline $\min$ & 5.0 & 75 & 1 & 23 & 13 & 0.2 & 0.1 & 1 & 0.1 & 0.1 & 0.4 & 0.8 & 0.19 \\
\hline $\max$ & 8.4 & 487 & 6 & 80 & 281 & 15 & 1 & 26 & 26 & 0.5 & 2.2 & 5.3 & 2.86 \\
\hline stdev & 1.4 & 133 & 2 & 8 & 83 & 6 & 0.2 & 8 & 9 & 0.2 & 0.7 & 1.5 & 0.87 \\
\hline \multicolumn{14}{|c|}{ La (11 samples) } \\
\hline Average & $7.4^{\mathrm{a}}$ & $364^{\mathrm{cb}}$ & $9^{b}$ & $114^{\mathrm{a}}$ & $228^{\mathrm{b}}$ & $27^{\mathrm{a}}$ & $0.7^{\mathrm{a}}$ & $17^{\mathrm{a}}$ & $18^{\mathrm{b}}$ & $0.72^{\mathrm{b}}$ & $1.5^{\mathrm{b}}$ & $3.0^{\mathrm{a}}$ & $1.47^{\mathrm{a}}$ \\
\hline $\min$ & 7.1 & 210 & 3 & 67 & 64 & 18 & 1 & 7 & 8 & 0.45 & 1.3 & 0.2 & 1.02 \\
\hline $\max$ & 7.5 & 487 & 16 & 172 & 506 & 75 & 2 & 33 & 40 & 1.22 & 2.4 & 5.0 & 1.66 \\
\hline stdev & 0.2 & 77 & 4 & 28 & 170 & 24 & 0.4 & 8 & 9 & 0.24 & 0.4 & 1.8 & 0.23 \\
\hline \multicolumn{14}{|c|}{ U (8 samples) } \\
\hline Average & $7.4^{\mathrm{a}}$ & $279^{\mathrm{ac}}$ & $12^{\mathrm{b}}$ & $66^{\mathrm{ab}}$ & $1611^{c}$ & $4^{\mathrm{a}}$ & $0.7^{\mathrm{a}}$ & $7^{\mathrm{a}}$ & $17^{\mathrm{b}}$ & $0.3^{\mathrm{a}}$ & $0.5^{\mathrm{a}}$ & $7.5^{\mathrm{b}}$ & $0.44^{\mathrm{bc}}$ \\
\hline $\min$ & 7.0 & 151 & 5 & 8 & 397 & 0.1 & 0.1 & 1 & 4 & 0.2 & 0.4 & 5.6 & 0.02 \\
\hline $\max$ & 8.5 & 485 & 21 & 157 & 2572 & 11 & 2 & 15 & 31 & 0.7 & 0.7 & 10.3 & 1.00 \\
\hline stdev & 0.5 & 134 & 6 & 52 & 845 & 4 & 0.6 & 6 & 11 & 0.2 & 0.1 & 1.9 & 0.29 \\
\hline \multicolumn{14}{|c|}{ Ka (7 samples) } \\
\hline Average & $5.6^{\mathrm{b}}$ & $292^{\mathrm{ac}}$ & $2^{\mathrm{a}}$ & $61^{\mathrm{ab}}$ & $101^{\mathrm{a}}$ & $10^{\mathrm{a}}$ & $0.3^{\mathrm{a}}$ & $5^{\mathrm{a}}$ & $7^{\mathrm{a}}$ & $0.4^{\mathrm{a}}$ & $0.7^{\mathrm{ab}}$ & $2.9^{\mathrm{a}}$ & $0.38^{\mathrm{bc}}$ \\
\hline $\min$ & 4.9 & 153 & 1 & 24 & 24 & 0.6 & 0.2 & 0.2 & 4 & 0.3 & 0.4 & 2.4 & 0.11 \\
\hline $\max$ & 6.5 & 450 & 3 & 162 & 209 & 31 & 0.4 & 20 & 14 & 0.7 & 1.1 & 3.6 & 1.07 \\
\hline stdev & 0.6 & 99 & 1 & 47 & 60 & 12 & 0.1 & 7 & 3 & 0.1 & 0.2 & 0.5 & 0.32 \\
\hline \multicolumn{14}{|c|}{ Kb (11 samples) } \\
\hline Average & $6.2^{\mathrm{b}}$ & $603^{b c}$ & $3^{\mathrm{a}}$ & $200^{c}$ & $127^{\mathrm{ab}}$ & $11^{\mathrm{a}}$ & $0.4^{\mathrm{a}}$ & $19^{\mathrm{a}}$ & $15^{\mathrm{ab}}$ & $0.7^{\mathrm{a}}$ & $0.8^{\mathrm{ab}}$ & $11.6^{\mathrm{b}}$ & $1.09^{\mathrm{ab}}$ \\
\hline $\min$ & 5.1 & 130 & 0.8 & 67 & 109 & 2 & 0.1 & 1 & 3 & 0.2 & 0.4 & 5.3 & 0.41 \\
\hline $\max$ & 7.0 & 1697 & 7 & 374 & 143 & 33 & 1 & 90 & 57 & 3.1 & 1.2 & 34.7 & 1.80 \\
\hline stdev & 0.6 & 477 & 2 & 24 & 11 & 10 & 0.3 & 25 & 16 & 0.8 & 0.3 & 10.3 & 0.60 \\
\hline \multicolumn{14}{|c|}{ PL (8 samples) } \\
\hline Average & $7.9^{\mathrm{a}}$ & $1496^{\mathrm{b}}$ & $11^{\mathrm{b}}$ & $90^{\mathrm{a}}$ & $146^{\mathrm{ab}}$ & $136^{\mathrm{a}}$ & $0.9^{\mathrm{a}}$ & $2^{\mathrm{a}}$ & $6^{\mathrm{a}}$ & $0.7^{\mathrm{b}}$ & $1.0^{\mathrm{ab}}$ & $17.1^{\mathrm{c}}$ & $0.44^{\mathrm{bc}}$ \\
\hline $\min$ & 7.5 & 448 & 8 & 39 & 27 & 28 & 0.3 & 0.3 & 3 & 0.4 & 0.4 & 13.0 & 0.10 \\
\hline $\max$ & 8.3 & 2990 & 21 & 140 & 197 & 559 & 2 & 5 & 7 & 1 & 3.1 & 24.3 & 1.50 \\
\hline stdev & 0.3 & 1014 & 4 & 33 & 51 & 187 & 0.5 & 2 & 2 & 0.3 & 1.0 & 3.9 & 0.48 \\
\hline
\end{tabular}

3.2. Anogia. Anogia soils contain abundant serpentine in both $63 \mu \mathrm{m}$ and $2 \mu \mathrm{m}$ soil fractions (Table 1). Serpentine is a typical constituent of ultramafic rocks (ophiolites) and outcrops in the area. The presence of talc in the silt soil fraction can also be attributed to the bedrock. Quartz content in the silt fraction is not related to the parent material. Chlorite in both silt and clay soil fractions could be either primary (from ultramafic rocks) or secondary mineral. Smectite in the clay fraction is a secondary mineral.

The chemical composition of Anogia soils resembles that of ultramafic rocks with $\mathrm{SiO}_{2}$ content $<45 \%$ and high $\mathrm{MgO}$ concentration (26.4\%) (Table 2).

Anogia soils exhibit an average $\mathrm{pH}$ value of 7.4. Electrical conductivity is rather low $(279 \mu \mathrm{S} / \mathrm{cm})$. Magnesium shows high availability in Anogia soils $(1611 \mathrm{mg} / \mathrm{kg}$ ) whereas potassium and calcium are rather low (66 and $4 \mathrm{mg} / \mathrm{kg}$, resp.) (Table 3).
Anogia samples display the highest cation exchange capacity $(12 \mathrm{meq} / 100 \mathrm{~g})$ compared to the CEC of the other soils (Table 3 ). Anogia soils are coarse grain (sandy loam).

3.3. Kantanos and Kantanos-Kountoura. Kantanos and Kantanos-Kountoura soils contain abundant illite, kaolinite, and quartz (Table 1). Quartz is the predominant mineral in the silt fraction $(<63 \mu \mathrm{m})$ for both $\mathrm{Ka}$ and $\mathrm{Kb}$ soils. Illite and kaolinite are present in both $63 \mu \mathrm{m}$ and $2 \mu \mathrm{m}$ soil fractions and both are typical products of weathered micaceous rocks such as those in phyllites-quartzites series. However, although the silt fraction of the two soils has comparable mineralogical composition, the clay fraction of Ka soil is rich in kaolinite whereas that of $\mathrm{Kb}$ soil has high illite content (Table 1).

$\mathrm{Ka}$ soils exhibit higher concentration of $\mathrm{SiO}_{2}(72.1 \%)$ compared to Kb soils (62.2\%) (Table 2). 


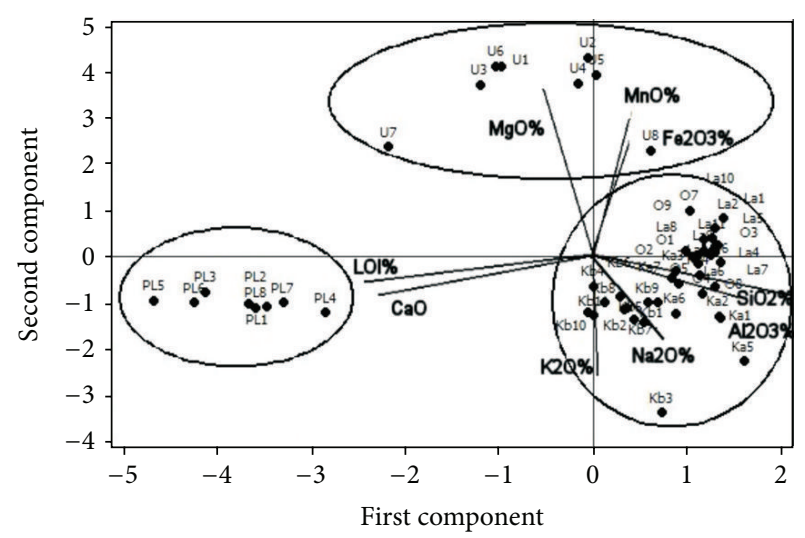

(a)

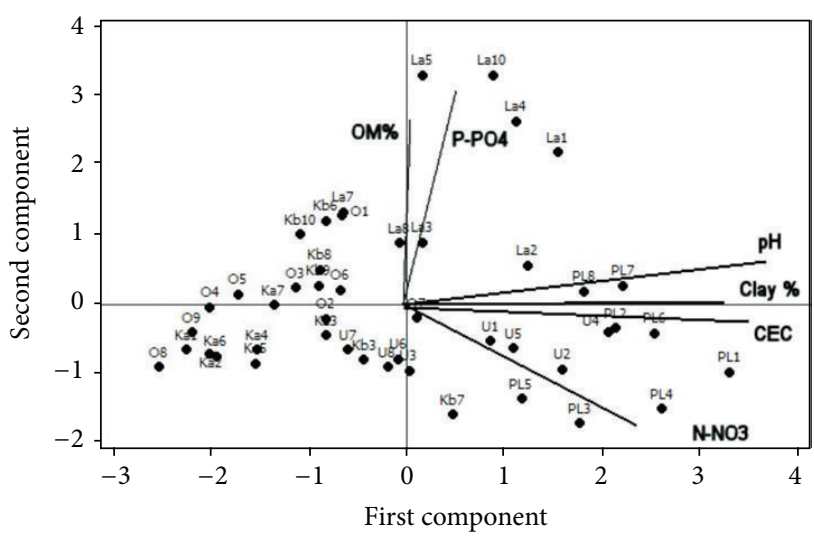

(b)

Figure 2: (a) PCA of chemical analysis $\left(\mathrm{Na}_{2} \mathrm{O}, \mathrm{MgO}, \mathrm{K}_{2} \mathrm{O}, \mathrm{Fe}_{2} \mathrm{O}_{3}, \mathrm{MnO}, \mathrm{CaO}, \mathrm{Al}_{2} \mathrm{O}_{3}, \mathrm{SiO}_{2}\right.$, and LOI). (b) PCA of macronutrients availability $\left(\mathrm{N}-\mathrm{NO}_{3}, \mathrm{P}-\mathrm{PO}_{4}\right.$ ) and physical parameters (clay content: clay\%, organic content: OC\%, and cation exchange capacity: CEC). 54 soil samples from Omalos Plateau (O), Lasithi Plateau (La), Kantanos (Ka, Kb) Anogia (U), and Platanos (PL). Variable axes are depicted in the figure.

Low $\mathrm{pH}$ values are observed for soil samples from $\mathrm{Ka}$ and $\mathrm{Kb}(5.6,6.2)$, which are related to $\mathrm{SiO}_{2}$-rich parent materials (Phyllites-Quartzites). Electrical conductivity exhibits spatial variability for both areas and the average value is higher for $\mathrm{Kb}$ soils (Ka: 292, Kb: $603 \mu \mathrm{S} / \mathrm{cm}$ ). Potassium concentration in extraction solutions from the $\mathrm{Kb}$ soils is higher $(200 \mathrm{mg} / \mathrm{kg}$ ) compared to that from Ka soils $(61 \mathrm{mg} / \mathrm{kg}$ ) something that is in accordance with the higher illite content in the clay fraction for $\mathrm{Kb}$ soils (Tables 1 and 3).

$\mathrm{Ka}$ and $\mathrm{Kb}$ soils show low CEC (Ka: $2.1 \mathrm{meq} / 100 \mathrm{~g}, \mathrm{~Kb}$ : $3.1 \mathrm{meq} / 100 \mathrm{~g}$ ). Moreover, soils from $\mathrm{Ka}$ and $\mathrm{Kb}$ areas are sandy loam and sandy clay loam, respectively.

3.4. Platanos. Platanos soils contain abundant calcite in both the silt and clay fractions which is related to sedimentation in shallow marine basins [46] (Table 1). Platanos soils are developed over marly limestones and sandstones (Neocene rocks). Smectite is present in the clay fraction.

On Table 2 the high $\mathrm{CaO}(26.4 \%)$ and $\mathrm{SiO}_{2}(24.2 \%)$ contents are illustrated and are typical for submarine sediments with marly limestones and sandstones. $\mathrm{MgO}$ is noticeable (2.45\%), whereas high loss on ignition (LOI) is attributed to calcite presence.

PL soils exhibit the highest $\mathrm{pH}$ values compared to other soils (in average 7.9, standard deviation 0.3 ) which can be related to the high content of basic cations $\left(\mathrm{Ca}^{2+}: 125 \mathrm{mg} / \mathrm{kg}\right)$ in extraction solution (Table 3). Moreover, PL soils have the highest electrical conductivity $(1496 \mu \mathrm{S} / \mathrm{cm})$.

Platanos samples exhibit the second higher cation exchange capacity (CEC) compared to other soils $(11 \mathrm{meq} /$ $100 \mathrm{gr}$ ). Grain size distribution is that of clay loam for PL soils.

3.5. Principal Component Analysis. The chemical analysis (XRF) is presented in Table 2. Figure 2(a) shows the Principal Components Analysis (PCA) results for 54 samples with variables the chemical species obtained by XRF analysis. The first three principal components describe $81 \%$ of the total variability. Three groups of samples are set, that is, PL samples (high Ca content), U soils (high Mg content), and $\mathrm{Ka}, \mathrm{Kb}, \mathrm{O}$, and $\mathrm{La}$ soil samples (high $\mathrm{Si}_{2} \mathrm{O}$ content) (groups in circles in Figure 2(a)). The first component (34\% variability) correlates $\mathrm{Si}_{2} \mathrm{O}$ and $\mathrm{Al}_{2} \mathrm{O}_{3}$, the second component (32\% variability) correlates $\mathrm{MnO}, \mathrm{Fe}_{2} \mathrm{O}_{3}$, and $\mathrm{MgO}$, and the third principal component strongly correlates $\mathrm{K}_{2} \mathrm{O}$ and $\mathrm{Al}_{2} \mathrm{O}_{3}$. The categorization of $\mathrm{Ka}, \mathrm{Kb}, \mathrm{O}$, and $\mathrm{La}$ in the same group shows common chemical characteristics of those soil samples. Figure 2(b) shows another PCA that is applied for physical and chemical variables such as clay content, $\mathrm{OM}, \mathrm{CEC}, \mathrm{pH}, \mathrm{N}-\mathrm{NO}_{3}$, and $\mathrm{P}-\mathrm{PO}_{4}$. The first three principal components (PCs) captured $75 \%$ of the variability and there is an obvious correlation between $\mathrm{CEC}, \mathrm{pH}$, clay content, and $\mathrm{N}-\mathrm{NO}_{3}$ content. Samples from La show some increase in P$\mathrm{PO}_{4}$ that is related to organic content. The first PC (34\% of variability) correlates the $\mathrm{CEC}$ and $\mathrm{N}-\mathrm{NO}_{3}$ content with clay content and $\mathrm{pH}$. The second PC ( $22 \%$ of variability) strongly correlates $\mathrm{OM} \%$ and $\mathrm{P}-\mathrm{PO}_{4}$. The third $\mathrm{PC}$ ( $19 \%$ of variability) correlates the $\mathrm{OM} \%$ with $\mathrm{N}-\mathrm{NO}_{3}$.

Figure 3(a) shows the PCA analysis for all soil samples for variables such as macronutrients content $\left(\mathrm{K}^{+}, \mathrm{Mg}^{2+}\right.$, and $\left.\mathrm{Ca}^{2+}\right), \mathrm{OM} \%$, clay content, and total illite content in both silt and clay fractions. The first three principal components described the $75 \%$ of total variability. The striking feature in this analysis is the first principal component that describes $34 \%$ of total variability and sets $\mathrm{K}^{+}$content, organic content, and illite content to be analogous. The illite content is referred to as corrected since the total concentration percentage includes illite in both silt and clay fractions and normalized to 100 . The second PC shows (23\% variability) that $\mathrm{Ca}^{2+}$ is related to clay content and the third PC ( $20 \%$ variability) correlates $\mathrm{Mg}^{2+}$ and $\mathrm{K}^{+}$with clay content. Figure 3(b) shows the PCA for all samples with variables, only the macronutrient availability. It is clear that $\mathrm{K}^{+}$and $\mathrm{Mg}^{2+}$ availability in soils is relatively the same in all samples and deviates only for Anogia soils (U-samples in circle Figures 3(a) and 3(b)) and some soil samples from Platanos area (PL-arrows in Figures 3(a) and 3(b)). Kbll sample (arrow in Figures 3(a) and 3(b)) exhibits higher $\mathrm{K}^{+}$availability compared to all samples. The first two 


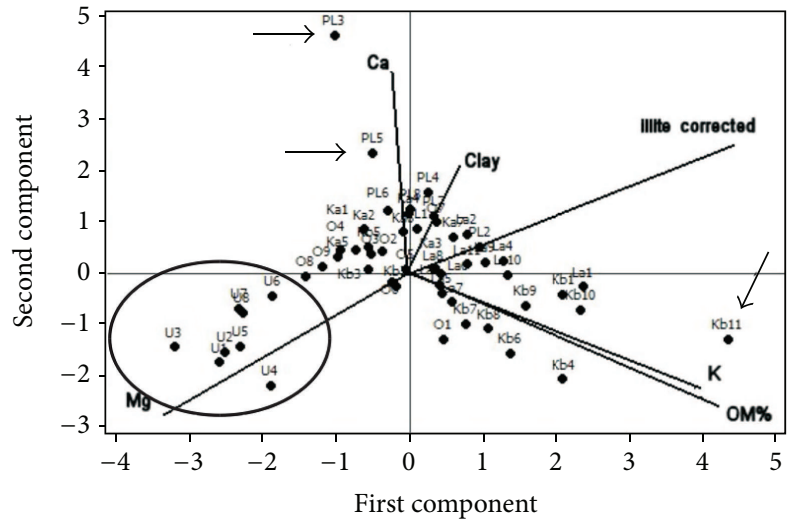

(a)

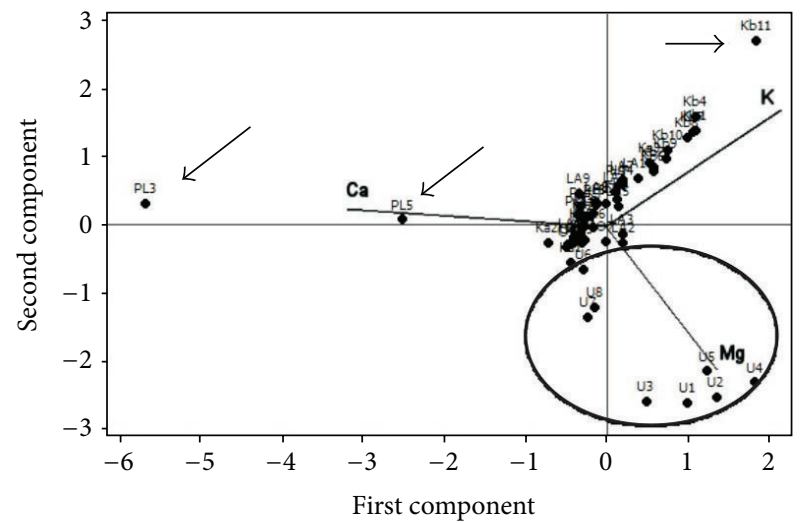

(b)

FIGURE 3: (a) PCA analysis of macronutrients availability $\left(\mathrm{Ca}^{2+}, \mathrm{Mg}^{2+}\right.$, and $\mathrm{K}^{+}$) and physical characteristics (clay content: clay\%, organic content: OC\%). (b) PCA analysis of macronutrients availability $\left(\mathrm{Ca}^{2+}, \mathrm{Mg}^{2+}\right.$, and $\left.\mathrm{K}^{+}\right) .54$ soil samples included from Omalos Plateau (O), Lasithi Plateau (La), Kantanos (Ka, Kb) Anogia (U), and Platanos (PL). The variable axes are depicted in the figure.

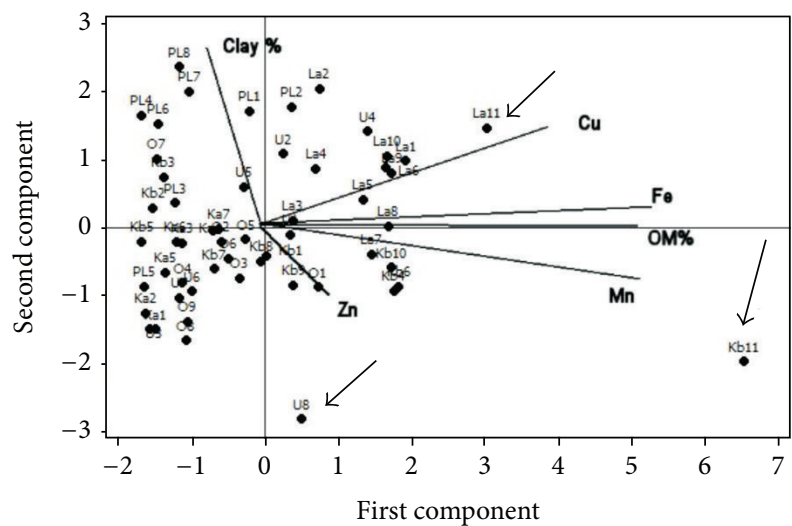

(a)

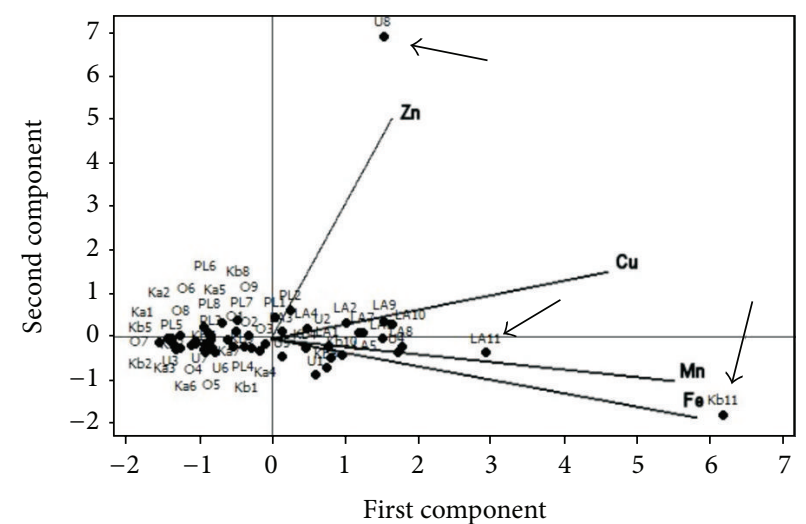

(b)

FIGURE 4: (a) PCA analysis of micronutrients availability $\left(\mathrm{Zn}^{2+}, \mathrm{Cu}^{2+}, \mathrm{Fe}^{2+}\right.$, and $\left.\mathrm{Mn}^{2+}\right)$ and physical characteristics (clay content: clay\%, organic content: OC\%). (b) PCA analysis of micronutrients availability $\left(\mathrm{Zn}^{2+}, \mathrm{Cu}^{2+}, \mathrm{Fe}^{2+}\right.$, and $\left.\mathrm{Mn}^{2+}\right) .54$ soil samples from Omalos Plateau $(\mathrm{O})$, Lasithi Plateau (La), Kantanos (Ka, Kb) Anogia (U), and Platanos (PL). The variable axes are depicted in the figure.

PCs capture $73 \%$ of variability and $\mathrm{Mg}^{2+}$ related positively to $\mathrm{K}^{+}$(first PC-37\% variability) whereas $\mathrm{Ca}^{2+}$ and $\mathrm{Mg}^{2+}$ are negatively correlated with $\mathrm{K}^{+}$(second $\mathrm{PC}-36 \%$ variability).

Micronutrients $\left(\mathrm{Zn}^{2+}, \mathrm{Cu}^{2+}, \mathrm{Fe}^{2+}\right.$, and $\left.\mathrm{Mn}^{2+}\right)$, clay content, and $\mathrm{OM} \%$ are the variables for the PCA depicted in Figure 4(a). The first 3 PCs explain the $79 \%$ of the variability. The first PC (39\% of variability) shows high correlation with organic content for all micronutrients apart from $\mathrm{Zn}^{2+}$. The second PC (21\% variability) interrelates $\mathrm{Cu}^{2+}$ content to clay content. The third PC (19\% variability) shows low interrelation between $\mathrm{Fe}^{2+}$ and $\mathrm{OM} \%$ and high correlation with $\mathrm{Cu}^{2+}$ and $\mathrm{Zn}^{2+}$. Figure 4(b) shows PCA for the micronutrients $\left(\mathrm{Zn}^{2+}, \mathrm{Cu}^{2+}, \mathrm{Fe}^{2+}\right.$, and $\left.\mathrm{Mn}^{2+}\right)$ and it is obvious that all samples are gathered in a cloud and only three samples are deviated (shown with black arrows in Figures 4(a) and 4(b)). The first two PCs capture $73 \%$ of total variability. The first PC (47\% variability) correlates $\mathrm{Fe}^{2+}$ with $\mathrm{Cu}^{2+}$ and $\mathrm{Mn}^{2+}$, and the second PC (26\% variability) correlates $\mathrm{Zn}^{2+}$ and $\mathrm{Cu}^{2+}$.

\section{Discussion}

4.1. Mineralogy and Chemical Analysis of Soils in relation to Different Parent Material. As it is expected, parent material influences primary mineral phases of soils. Two main reasons impose differences in the soil samples from Omalos Plateau and Lasithi Plateau and these are differences in the parent material and differences in the amount of precipitation in those areas. The presence of feldspars and chlorites and the lower quartz content in La soils compared to $\mathrm{O}$ soils are attributed to differences in the lithology of the weathering products (Table 1). This can be attributed to lithology differences of the surrounding rocks (phyllites and quartzites series) which they supplied with weathered products (sediments), both plateaus. In western Crete, phyllites and quartzites are dominated by quartz (Omalos Plateauquartzites), whereas in eastern Crete they have high mica content (Lasithi Plateau-phyllites). The presence of less illite and more kaolinite in $\mathrm{O}$ soils compared to La soils can be attributed to higher precipitation in O plateau compared to 
La plateau. Omalos Plateau is situated in higher elevation compared to Lasithi Plateau, whereas apart from the orographic gradient there is also strong directional gradient since western parts of the island gets more rain than the eastern part and that is demonstrated by recent studies (i.e., 1190$1670 \mathrm{~mm} / \mathrm{a}$ in Omalos Plateau, $720-1190 \mathrm{~mm} / \mathrm{a}$ in Lasithi Plateau) [47, 48]. Kourgialas et al. [49] presented the strong rainfall gradient due to elevation differences $(y=0.7105 *$ $x+578.4, y=$ rain, and $x=$ elevation).

The silt fraction of Anogia soils exhibits characteristic primary mineralogy with serpentine and talc as inherited from ultramafic rocks (Table 1). Smectite (a secondary mineral) in clay fraction can be attributed to $\mathrm{Mg}$ abundance in soil. The detection of quartz is noteworthy; a possible explanation for the presence of quartz may be dust deposition [50, 51].

$\mathrm{Ka}$ and $\mathrm{Kb}$ soils have quartz, feldspars, and phyllosilicates (paragonite) in silt and clay fractions which are related to phyllites-quartzite parent material. Ka soils exhibit differences in secondary minerals compared to $\mathrm{Kb}$ soils. $\mathrm{Ka}$ soils contain lower illite in clay fraction compared to $\mathrm{Kb}$ soils, which is attributed to differences within the phyllites and quartzites series ( $\mathrm{Kb}$ soils less acidic: low presence of quartzites) since both sampling areas are in the same elevation. This is an evident that soils from different lithology exhibit different content of secondary mineralogy like illite under the same climatic conditions (same amount of rain).

Platanos soils show mineralogy which is characteristic of the calcaric Neocene sediments (parent material) with abundant calcite in both silt and clay fractions. The presence of smectite in the PL soils is linked to $\mathrm{MgO}$ presence in chemical analysis. PL soils contain illite, which might be secondary and/or primary sedimentary mineral.

Smectite is present in soils with different lithological characteristics (i.e., ultramafic: U, alluvial: La, and limestone: $\mathrm{PL})$. This is an indication that factors like precipitation and drainage of soils affect concentration of basic cations (i.e., $\mathrm{Mg}^{2+}$ and $\mathrm{Ca}^{2+}$ ) favouring the formation of smectite. This is also evident from bulk chemical analysis where U, PL, and La exhibit significant $\mathrm{Mg}^{2+}$ concentrations (Table 2).

Bulk chemical analysis of soils reflects the main characteristics of the parent materials (Table 2, Figure 2). The striking feature is the relative common chemical characteristics for $\mathrm{O}$, $\mathrm{La}, \mathrm{Ka}$, and $\mathrm{Kb}$ soils (Figure 2) which is evidence that alluvial sediments in Omalos and Lasithi Plateau are comprised of weathered products of metamorphic schists like those in $\mathrm{Ka}$ and $\mathrm{Kb}$ sites. Thus, $\mathrm{O}$ and $\mathrm{La}$ soils exhibit high $\mathrm{SiO}_{2}$ concentration in bulk chemical analysis related to alluvial rocks lithology. $\mathrm{O}$ soils exhibit higher $\mathrm{SiO}_{2}$ content compared to La soils probably due to higher precipitation in Omalos Plateau as it has been already mentioned, which promotes the increase of elements leaching and the increase of weathering resistant material like quartz. The highest $\mathrm{MgO}$ and $\mathrm{FeO}$ concentrations are found in $\mathrm{U}$ soils since they are inherent characteristics of its parent material (serpentine). $\mathrm{Kb}$ and $\mathrm{Ka}$ soils exhibit the highest $\mathrm{SiO}_{2}$ concentration that is related to their parent materials (phyllites and quartzites); Kb soils show lower $\mathrm{SiO}_{2}$ concentration compared to Ka due to less acidic parent material in the former as it has already been mentioned. PL soils show the highest $\mathrm{CaO}$ content compared to the other soils related to a Neocene sediment mixture of sand and marly limestones.

Soil texture shows that sedimentary parent material exhibits finer grain size soils (PL, O, and La), whereas soils with nonsedimentary parent material are coarser grained (Ka, Kb, and U). Parent material of the PL soils (soils with finer grains) is a biochemical sedimentary rock and the deposition of fine grain calcite is common [46].

4.2. Macronutrients and Micronutrients in relation to Different Soil Parent Material. PCA analysis showed strong interrelation between potassium content, organic matter, and illite content (Figure 3(a)). In addition, $\mathrm{Ca}^{2+}$ is related to clay content and negatively related to $\mathrm{Mg}^{2+}$ and $\mathrm{K}^{+}$. Moreover, it is obvious from Figure 3(a) that most of the soil samples are gathered in one "cloud" without separating any group, except Anogia soils (U). The same is shown from PCA, where three macronutrients are considered as variables $\left(\mathrm{K}^{+}, \mathrm{Mg}^{2+}\right.$, and $\mathrm{Ca}^{2+}$ ) (Figure 3(b)). The previous shows soils from different lithologies (alluvial-O, La metamorphic $\mathrm{Ka}, \mathrm{Kb}$, and calcaric $\mathrm{PL}$ ) to have identical availability of macronutrients and the samples deviating from those are Anogia samples due to high availability of $\mathrm{Mg}$ (samples in circles, Figures 3(a) and 3(b)) and some samples from Platanos area due to high availability of $\mathrm{Ca}$ (arrows in Figure 3(b)). In other words it is shown that all soils apart from Anogia samples and some from Platanos area are in a common state regarding $\mathrm{K}^{+}, \mathrm{Mg}^{2+}$, and $\mathrm{Ca}^{2+}$ availability. Only in Anogia soils, lithology characteristics of the parent material influence macronutrient availability such as $\mathrm{Mg}^{2+}$, whereas the case is the same with some samples from Platanos area. Stutter et al. [7] showed that a strong relationship exists between basic cations (i.e., $\mathrm{Ca}^{2+}$, $\mathrm{Mg}^{2+}$ ) and basic parent material in soils. The high calcite content in PL soils is due to the origin of the Neocene parent material (sediment pool in shallow marine environment) [46] which mainly consist of unconsolidated crystals of calcite, clay minerals, and quartz. To verify the results, $t$-tests were applied for all samples to identify significant different average values. As it is shown in Table 3, most of the samples are not significantly different regarding $\mathrm{K}^{+}$availability, apart from $\mathrm{Kb}$ samples, which show higher illite content. The previous is observed also in Figure 3(b) where $\mathrm{Kb}$ samples are along $\mathrm{K}^{+}$variable axis. Omalos samples exhibit the lowest $\mathrm{K}^{+}$ availability and they are slightly different to La soil samples which are probably connected with increased $\mathrm{K}$ leaching due to higher precipitation in Omalos Plateau compared to Lasithi Plateau. In addition, potassium availability in our case is controlled by both illite content and organic matter, which is an unusual case and it is observed only when organic matter contribution in the total CEC is less than $15 \%$, which has been shown by detailed study of Poonia and Niederbudde [52] on the $\mathrm{K}^{+}$absorption in soils. The aforementioned is verified by the weak interrelation of OM\% and CEC as revealed in PCA (Figure 2(b)). Visualization of the aforementioned is shown also in Figures 5(a) and 5(b) where plots of $\mathrm{K}^{+}$availability versus illite content and OM content share an almost identical $R^{2}$ (0.53 to 0.59$)$. 


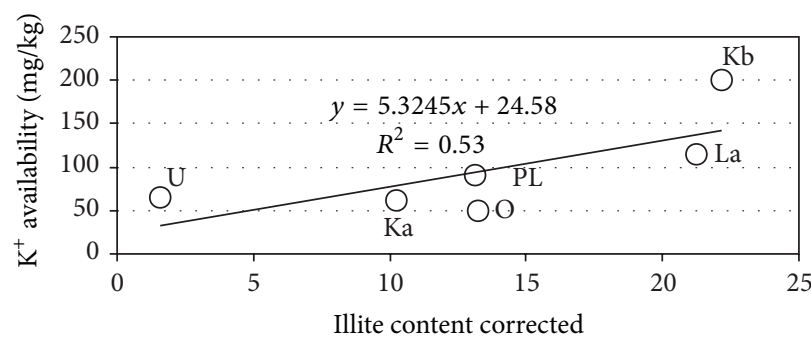

(a)

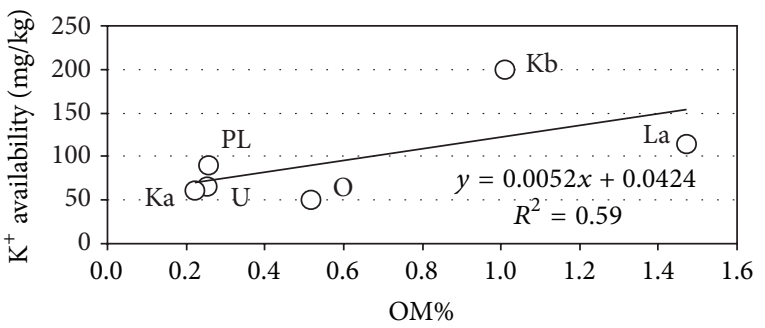

(b)

Figure 5: (a) Potassium availability versus \% illite corrected content calculated from both silt and clay fractions normalized to $100 \%$. (b) Potassium availability versus organic matter \%. Fitted lines and $R^{2}$ are also shown.

Identical results can be inferred for $\mathrm{Mg}^{2+}$ availability; thus, all samples apart from $\mathrm{U}$ exhibit the same $\mathrm{Mg}^{2+}$ and there is again a small difference between $\mathrm{O}$ and La samples as it is for potassium. Calcium shows no statistical difference in average values among all soil samples and that is also the case for the soils with calcaric parent material. Someone could infer that the in situ uncultivated soils investigated in Crete regarding $\mathrm{K}^{+}, \mathrm{Mg}^{2+}$, and $\mathrm{Ca}^{2+}$ have reached a common stage in the availability of these nutrient elements. Differences are observed in soils like Anogia (ultramafic parent material) and in some soils in Platanos (calcaric parent material), where the lithological factor is still strong and overcomes the low organic matter availability.

Figure 4(a) shows that the micronutrients are mostly associated with organic content. Micronutrients availability in 54 soils is relatively identical as it is described in Figure 4(b). Only three samples exhibit high values of certain elements (arrows in Figures 4(a) and 4(b)), an observation that can be related to spatial lithological and/or chemical differences. Indeed, Table 3 shows on average identical statistical values for most of the micronutrients. Fe exhibits on average statistical different values only for the areas of $\mathrm{La}$ and $\mathrm{U}$ : the former is related to the high organic content (i.e., Lall) whereas the latter is related to the higher content of minerals rich with $\mathrm{Fe}$ (i.e., chlorite) and this is also obvious in bulk chemistry of $\mathrm{U}$ soils (Table 2). $\mathrm{U}$ soils exhibit high $\mathrm{pH}$, which is crucial for low leaching rate of available $\mathrm{Mn}^{2+}$ and $\mathrm{Fe}^{2+}$ into soil solution [53]. In contrast, soils with low $\mathrm{pH}$ (i.e., Kb11, Figures 4(a) and 4(b)) show higher availability in $\mathrm{Mn}^{2+}$ and $\mathrm{Fe}^{2+}$ and that is also observed by other researchers [54]. Thus, $\mathrm{pH}$ seems to influence availability of $\mathrm{Mn}^{2+}$ and $\mathrm{Fe}^{2+}$. In addition, $\mathrm{Cu}^{2+}$ and $\mathrm{Zn}^{2+}$ concentrations are low and they do not vary significantly among the soils, probably due to the relatively low organic matter content (see Section 4.3) and/or the already low concentrations of these ions in the bedrock geology (limestones, ultra-mafic rocks, etc.).

\subsection{Organic Matter, Nitrates, and Phosphates Availability in} relation to Different Parent Material. OM content is similar in most of the soil samples and it is slightly lower than typical Mediterranean soils (1 to 1.5\%) [55-58], except $\mathrm{La}$ and $\mathrm{Kb}$ soils due to denser vegetation in those areas (shrubs, etc.). Two observations are obvious: parent material origin does not affect the OM content of uncultivated soils in Crete and that Mediterranean climate is a crucial regulating factor of OM content in soils. López-Piñeiro et al. [59] mentioned that many soils from the Mediterranean region are poor in organic matter. The same is observed also for nitrates and phosphates in the soils studied here. Fast decomposition of OM due to climatic conditions (low rainfall, high temperatures) and low vegetation grow (low input of organic residues) lead to high rates of $\mathrm{N}$ mineralization and finally high leaching of nitrates through rainfall during winter time and especially by first flush events [57, 60-65]. The nitrogen-nitrate shows correlation with clay content this is related probably to positively charged sites in clays which has also been observed by others, especially in deeper soil horizons in the absence of organic matter [66]. Figure 2(b) shows $\mathrm{P}_{-} \mathrm{PO}_{4}$ to be strongly correlated with organic matter. The aforementioned are also evident in Table 3 where $\mathrm{P}_{-} \mathrm{PO}_{4}$ content is on average statistically different for La samples that also exhibit higher content of organic matter in some samples. The $\mathrm{N}-\mathrm{NO}_{3}$ abundance is different for PL soils, which are finer. $\mathrm{Kb}$ and $\mathrm{U}$ soils show also different $\mathrm{N}-\mathrm{NO}_{3}$ content which can be related to higher organic content and to the type of clay (i.e., smectite), respectively. More studies are needed in order to clarify these observations.

4.4. Soil Physicochemical Variations in relation to Different Soil Parent Material. Figure 2(b) shows that CEC is related to both clay content and $\mathrm{pH}$ and the correlation of organic content with CEC is rather weak. Only La sample exhibits high CEC which can be correlated with organic content which is different and higher compared to other soils in Crete. U, PL soils exhibit the highest CEC values and the highest smectite content compared to other soils and this is also verified by $t$-test. However, considering the highest theoretical CEC of smectite for U soils $(70-130 \mathrm{meq} / 100 \mathrm{~g})$ [67] and that only the clay fraction contributed to CEC, then $16 \%$ of the total CEC could be exchanged into extraction solution. Thus, smectite is not the only mineral contributed to CEC. Hence, Wauters et al. [68] referred to exchange sites that consist of sites in planar and/or interlayer clay minerals, humic substances, and frayed edge sites (FES) located at the edges of micaceous minerals. In addition, Fe-Mn oxide minerals can contribute to CEC $[69,70]$. Thus, in our case both edges of phyllosilicates minerals (i.e., serpentine, chlorite) and oxides surfaces could contribute to CEC. $\mathrm{pH}$ controls CEC of such surfaces. 


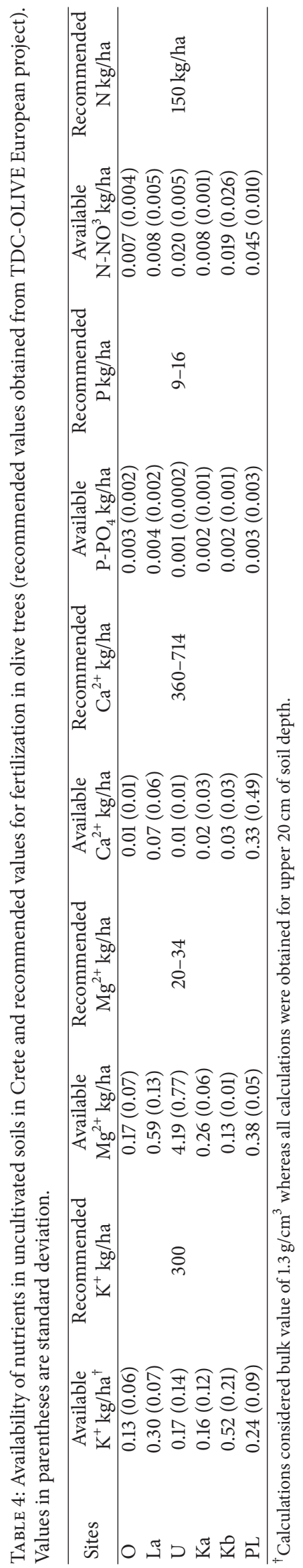


$\mathrm{PL}, \mathrm{U}$, and La soils exhibit high $\mathrm{pH}$ values, due to the high content of basic cations like $\mathrm{Mg}^{2+}$ and $\mathrm{Ca}^{2+}$, whereas soils like $\mathrm{Ka}$ and $\mathrm{Kb}$ exhibit low $\mathrm{pH}$, due to high content of silicon and depletion of basic cations. $\mathrm{O}$ and La soils exhibit different $\mathrm{pH}$ values despite their similar parent materials, due to differences within the alluvial deposits as already have been mentioned and/or the higher precipitation in Omalos Plateau. The dependence of CEC on $\mathrm{pH}$ is related to the presence of exchangeable sites on the edges of the silicate minerals and oxides and on the competitive adsorption of $\mathrm{H}^{+}$in exchangeable sites [71,72]. Thus, in the absence of significant organic matter, parent material affects directly the soil $\mathrm{pH}$ which in turn influences CEC.

4.5. Soil Quality in Fragile Undisturbed Soils of Crete. Finally the present study shows the fragile soil development in different lithological units of Crete. To visualize the low nutrient capacity of uncultivated soils in Crete, we consider the fertilization requirements of olive trees which are a widespread cultivation in Mediterranean area [73]. Table 4 shows the availability of macronutrients per hectare in the soils investigated and the recommended values for olive trees (in average rainfall $400-700 \mathrm{~mm}$ ). It is clearly shown that the availability of nutrients is at least $575,6,1647,3300$, and 3368 times lower than the recommended fertilization (TDCOlive project) values for olive trees cultivation. The previous values are calculated by comparing the area with the higher availability for each nutrient to the nutrient recommended value for olive trees cultivation. Thus, the soil states of the undisturbed soils in semiarid Mediterranean climatic conditions have developed soils of low organic content and low nutrient availability and only in certain cases like $\mathrm{Mg}^{2+}$ content in Anogia.

\section{Conclusions}

Conclusions from the results of the chemical and mineralogical analyses in undisturbed soils in Crete can be summarized to the following.

(i) Primary mineralogical phases and bulk chemical analysis of soils reflect parent material lithology; however, PCA revealed that most of the soils showed identical macronutrient availability irrespectively of the parent rock lithology. Only the case of $\mathrm{Mg}^{2+}$ shows higher availability in limited samples from ultramafic parent rock.

(ii) Most of the sampling sites show that micronutrients availability has reached a common stage and is low due to low organic content. Only few samples show higher micronutrient availability related possibly to local lithological differences without significantly statistically changing the overall arguments.

(iii) PCA revealed that potassium is low and it is controlled from both the secondary minerals and the organic content in soils.

(iv) Cation exchange capacity is low and it is connected to smectite presence, edges of minerals, and $\mathrm{pH}$ and no relation is identified to organic matter, with the exception of one sample from Lasithi Plateau.

(v) Nutrients like nitrogen, phosphorous, $\mathrm{Mn}^{2+}, \mathrm{Fe}^{2+}$, $\mathrm{Cu}^{2+}$, and $\mathrm{Zn}^{2+}$ are not correlated with the parent material, and all soils exhibit common behaviour while the availability in those nutrients is low.

(vi) Organic content in undisturbed soils in Mediterranean semiarid climatic conditions is low and it should be considered in future perspectives of soil modeling studies, soil management, and soil protection. Identically, macro- and micronutrients have been washed out in the undisturbed soils due to missing host sites like organic matter.

\section{Competing Interests}

The authors declare that they have no competing interests.

\section{Acknowledgments}

The project was cofunded by the European Social Fund and National Resources EPEAEK II-PYTHAGORAS. The authors are thankful for the economic support.

\section{References}

[1] P. Smith, M. F. Cotrufo, C. Rumpel et al., "Biogeochemical cycles and biodiversity as key drivers of ecosystem services provided by soils," Soil, vol. 1, no. 2, pp. 665-685, 2015.

[2] C. Decock, J. Lee, M. Necpalova, E. I. Pereira, D. M. Tendall, and J. Six, "Mitigating $\mathrm{N}_{2} \mathrm{O}$ emissions from soil: from patching leaks to transformative action," SOIL, vol. 1, no. 2, pp. 687-694, 2015.

[3] S. D. Keesstra, V. Geissen, K. Mosse et al., "Soil as a filter for groundwater quality," Current Opinion in Environmental Sustainability, vol. 4, no. 5, pp. 507-516, 2012.

[4] E. C. Brevik, A. Cerdà, J. Mataix-Solera et al., "The interdisciplinary nature of SOIL," SOIL, vol. 1, no. 1, pp. 117-129, 2015.

[5] F. Berendse, J. van Ruijven, E. Jongejans, and S. Keesstra, "Loss of plant species diversity reduces soil erosion resistance," Ecosystems, vol. 18, no. 5, pp. 881-888, 2015.

[6] J. Pastor and J. G. Bockheim, "Distribution and cycling of nutrients in an aspen-mixed-hardwood-spodosol ecosystem in northern Wisconsin," Ecology, vol. 65, no. 2, pp. 339-353, 1984.

[7] M. Stutter, S. Langan, and M. Cresser, "Weathering and atmospheric deposition signatures of base cations in upland soils of NE Scotland: their application to critical load assessment," Geoderma, vol. 116, no. 3-4, pp. 301-324, 2003.

[8] J. L. K. Vestin, K. Nambu, P. A. W. van Hees, D. Bylund, and U. S. Lundström, "The influence of alkaline and non-alkaline parent material on soil chemistry," Geoderma, vol. 135, pp. 97106, 2006.

[9] D. A. Wysocki, P. J. Schoeneberger, and H. E. Lagarry, "Soil surveys: a window to the subsurface," Geoderma, vol. 126, no. 1-2, pp. 167-180, 2005.

[10] R. C. Graham, W. R. Guertal, and K. R. Tice, "The pedologic nature of weathered rock," in Whole Regolith Pedology, D. L. Cremeens, R. B. Brown, and J. H. Huddleston, Eds., Special Publication no. 34, pp. 21-40, Soil Science Society of America (SSSA), Madison, Wis, USA, 1994. 
[11] B. A. Roberts and J. Proctor, The Ecology of Areas with Serpentinized Rocks: A World View, Kluwer Academic Publishers, Dordrecht, The Netherlands, 1992.

[12] F. Caravaca, A. Lax, and J. Albaladejo, "Organic matter, nutrient contents and cation exchange capacity in fine fractions from semiarid calcareous soils," Geoderma, vol. 93, no. 3-4, pp. 161$176,1999$.

[13] E. N. Hepper, D. E. Buschiazzo, G. G. Hevia, A. Urioste, and L. Antón, "Clay mineralogy, cation exchange capacity and specific surface area of loess soils with different volcanic ash contents," Geoderma, vol. 135, pp. 216-223, 2006.

[14] B. R. Egli, Ecology of the valleys in the mountains of Crete (Griechenland) [Ph.D. thesis], ETH, Zurich, Switzerland, 1993 (German).

[15] G. Nakos, "Relationships of bio-climatic zones and lithology with various characteristics of forest soils in Greece," Plant and Soil, vol. 79, no. 1, pp. 101-121, 1984.

[16] U. F. Dornsiepen and E. Manutsoglu, "Zur gliederung der phyllit-decke kretas und des peloponnes," Zeitschrift der Deutschen Geologischen Gesellschaft, vol. 145, pp. 286-304, 1994 (German).

[17] N. Fytrolakis, The geological structure of Crete [Ph.D. thesis], National Technical University of Athens, 1980.

[18] M. Manoutsoglou, E. Spyridonos, A. Soujon, and V. Jacobshagen, "Redesign of geological map and 3D simulation of the geological structure of Samaria gorge western Crete," in Proceedings of the 9th International Congress of the Geological Society of Greece, P. G. Marinos, G. C. Koukis, G. C. Tsiambaos, and G. C. Stournaras, Eds., pp. 29-36, Geological Society of Greece, Athens, Greece, September 2001.

[19] J. Quade, N. Solounias, and T. E. Cerling, "Stable isotopic evidence from paleosol carbonates and fossil teeth in Greece for forest or woodlands over the past $11 \mathrm{Ma}$," Palaeogeography, Palaeoclimatology, Palaeoecology, vol. 108, no. 1-2, pp. 41-53, 1994.

[20] M. Tsakona and V. Gekas, "Desertification in Crete and the effect of global warming," in Proceedings of the 5th International Conference on Environment, Ecosystems and Development (WSEAS '07), M. Otesteanu, S. Celikyay, N. Mastorakis, S. Lache, and F.-K. Benra, Eds., pp. 211-216, Tenerife, Spain, December 2007.

[21] N. J. Yassoglou and C. Kosmas, "Desertification in the Mediterranean Europe. A case study in Greece," RALA Report 200, Agricultural Research Institut, Reykjavik, Iceland, 1997.

[22] S. Banwart, "Save our soils," Nature, vol. 474, no. 7350, pp. 151152, 2011.

[23] A. Cerdà, "Relationships between climate and soil hydrological and erosional characteristics along climatic gradients in Mediterranean limestone areas," Geomorphology, vol. 25, no. 12, pp. 123-134, 1998.

[24] A. Cerda and H. Lavee, "Runoff an erosion during the gradient climatic attitude effect caused by the pasture in the Judean Deserts," Cuadernos Geograficos, no. 29, pp. 27-50, 1999.

[25] A. Cerdà, "Aggregate stability against water forces under different climates on agriculture land and scrubland in southern Bolivia," Soil and Tillage Research, vol. 57, no. 3, pp. 159-166, 2000.

[26] A. C. Campos, J. B. Etchevers, K. L. Oleschko, and C. M. Hidalgo, "Soil microbial biomass and nitrogen mineralization rates along an altitudinal gradient on the cofre de perote volcano (Mexico): the importance of landscape position and land use,"
Land Degradation and Development, vol. 25, no. 6, pp. 581-593, 2014.

[27] B. U. Choudhury, A. R. Fiyaz, K. P. Mohapatra, and S. Ngachan, "Impact of land uses, agrophysical variables and altitudinal gradient on soil organic carbon concentration of North-Eastern Himalayan Region of India," Land Degradation and Development, vol. 27, no. 4, pp. 1163-1174, 2016.

[28] J. Casana, "Mediterranean valleys revisited: linking soil erosion, land use and climate variability in the Northern Levant," Geomorphology, vol. 101, no. 3, pp. 429-442, 2008.

[29] S. Kéfi, M. Rietkerk, C. L. Alados et al., "Spatial vegetation patterns and imminent desertification in Mediterranean arid ecosystems," Nature, vol. 449, no. 7159, pp. 213-217, 2007.

[30] F. E. Stamati, N. P. Nikolaidis, D. Venieri, E. Psillakis, and N. Kalogerakis, "Dissolved organic nitrogen as an indicator of livestock impacts on soil biochemical quality," Applied Geochemistry, vol. 26, pp. S340-S343, 2011.

[31] F. E. Stamati, N. P. Nikolaidis, and J. L. Schnoor, "Modeling topsoil carbon sequestration in two contrasting crop production to set-aside conversions with RothC-calibration issues and uncertainty analysis," Agriculture, Ecosystems and Environment, vol. 165, pp. 190-200, 2013.

[32] P. Panagos, K. Christos, B. Cristiano, and G. Ioannis, "Seasonal monitoring of soil erosion at regional scale: an application of the G2 model in Crete focusing on agricultural land uses," International Journal of Applied Earth Observation and Geoinformation, vol. 27, pp. 147-155, 2014.

[33] J. Krahl, G. Kauffmann, H. Kozur, D. Richter, O. Förster, and F. Heinritzi, "New data on the biostratigraphie of Phyllite group and the Trypali group on the island of Crete (Greece)," Geologische Rundschau, vol. 72, pp. 1147-1166, 1983 (German).

[34] R. Greiling and W. Skala, "The development of pre-neogenen tectonism in Phyllite-Quartzite series," Zeitschrift der Deutschen Geologischen Gesellschaft, vol. 127, pp. 429-433, 1976 (German).

[35] E. Seidel, The petrology of phyllites-quartzites series crete [Ph.D. thesis], Habilitationsschrift TU Braunschweig, 1978 (German).

[36] G. J. Bouyoucos, "Hydrometer method improved for making particle size analyses of soils," Agronomy Journal, vol. 54, no. 5, pp. 464-465, 1962.

[37] G. W. Thomas, "Soil pH and soil acidity", in Chemical Methods Methods of Soil Analysis Part 3, D. L. Sparks, Ed., vol. 3, pp. 487489, ASA and SSSA, Madison, Wis, USA, 1996.

[38] C. A. Bower, R. F. Reitemeier, and M. Fireman, "Exchangeable cation analysis of saline and alkali soils," Soil Science, vol. 73, no. 4, pp. 251-261, 1952.

[39] G. W. Thomas, "Exchangeable cations," in Methods of Soil Analysis. Part 2, A. L. Page, R. H. Miller, and D. R. Keeney, Eds., Agronomy Monograph 9, pp. 159-165, ASA and SSSA, Madison, Wis, USA, 1982.

[40] W. L. Lindsay and W. A. Norvell, "Development of a DTPA soil test for zinc, iron, manganese, and copper," Soil Science Society of America Journal, vol. 42, no. 3, pp. 421-428, 1978.

[41] S. R. Olsen, C. V. Cole, F. S. Watanabe, and L. A. Dean, Estimation of Available Phosphorus in Soils by Extraction with Sodium Bicarbonate, USDA Circ, 1954.

[42] D. R. Keeney, D. W. Nelson et al., "Nitrogen-inorganic forms," in Methods of Soil Analysis. Part 2, A. L. Page, D. R. Keeney, D. E. Baker, R. H. Miller, R. Ellis Jr., and J. D. Rhoades, Eds., Agronomy Monograph 9, pp. 643-698, ASA and SSSA, Madison, Wis, USA, 1982. 
[43] A. Walkley and I. A. Black, "An examination of the degtjareff method for determining soil organic matter, and a proposed modification of the chromic acid titration method," Soil Science, vol. 37, no. 1, pp. 29-38, 1934.

[44] M. E. Sumner and W. P. Miller, "Cation exchange capacity and exchange coefficients," in Methods of Soil Analysis Part 3, D. L. Sparks, Ed., SSSA.1201-1229, pp. 1201-1229, Chemical Methods, Madison, Wis, USA, 1996.

[45] R. Dohrmann, "Problems in CEC determination of calcareous clayey sediments using the ammonium acetate method," Journal of Plant Nutrition and Soil Science, vol. 169, no. 3, pp. 330-334, 2006.

[46] H. G. Reading, Sedimentary Environment: Processes, Facies and Stratigraphy, Blackwell Science, Oxford, UK, 3rd edition, 1996.

[47] S. Naoum and I. K. Tsanis, "Orographic precipitation modeling with multiple linear regression," Journal of Hydrologic Engineering, vol. 9, no. 2, pp. 79-102, 2004.

[48] S. Naoum and I. K. Tsanis, "Temporal and spatial variation of annual rainfall on the island of Crete, Greece," Hydrological Processes, vol. 17, no. 10, pp. 1899-1922, 2003.

[49] N. N. Kourgialas, G. P. Karatzas, and N. P. Nikolaidis, "Development of a thresholds approach for real-time flash flood prediction in complex geomorphological river basins," Hydrological Processes, vol. 26, no. 10, pp. 1478-1494, 2012.

[50] D. H. Yaalon, "Saharan dust and desert loess: effect on surrounding soils," Journal of African Earth Sciences, vol. 6, no. 4, pp. 569-571, 1987.

[51] D. H. Yaalon, "Soils in the Mediterranean region: what makes them different?" Catena, vol. 28, no. 3-4, pp. 157-169, 1997.

[52] S. R. Poonia and E. A. Niederbudde, "Exchange equilibria of potassium in soils, V. Effect of natural organic matter on $\mathrm{K}-\mathrm{Ca}$ exchange," Geoderma, vol. 47, no. 3-4, pp. 233-242, 1990.

[53] W. L. Lindsay and F. R. Cox, "Micronutrient soil testing for the tropics," in Micronutrients in Tropical Food Crop Production. Fertilizer Research, P. L. G. Vlek, Ed., pp. 169-200, Springer Netherlands, 1985.

[54] J. C. Katyal and B. D. Sharma, "DTPA-extractable and total Zn, $\mathrm{Cu}, \mathrm{Mn}$, and $\mathrm{Fe}$ in Indian soils and their association with some soil properties," Geoderma, vol. 49, no. 1-2, pp. 165-179, 1991.

[55] N. Yassoglou, C. Kosmas, and N. Moustakas, "The red soils, their origin, properties, use and management in Greece," Catena, vol. 28, no. 3-4, pp. 261-278, 1997.

[56] P. Dlapa, M. B. Bodí, J. Mataix-Solera, A. Cerdà, and S. H. Doerr, "Organic matter and wettability characteristics of wildfire ash from Mediterranean conifer forests," CATENA, vol. 135, pp. 369-376, 2015.

[57] J. L. Costa, V. Aparicio, and A. Cerdà, "Soil physical quality changes under different management systems after 10 years in the Argentine humid pampa," Solid Earth, vol. 6, no. 1, pp. 361371, 2015.

[58] N. Yazdanpanah, M. Mahmoodabadi, and A. Cerdà, "The impact of organic amendments on soil hydrology, structure and microbial respiration in semiarid lands," Geoderma, vol. 266, pp. 58-65, 2016.

[59] A. López-Piñeiro, S. Murillo, C. Barreto et al., "Changes in organic matter and residual effect of amendment with twophase olive-mill waste on degraded agricultural soils," Science of the Total Environment, vol. 378, no. 1-2, pp. 84-89, 2007.

[60] S. L. Tisdale, W. L. Nelson, J. D. Beaton, and J. L. Halvin, Soil Fertility and Fertilizers, Macmillan, New York, NY, USA, 5th edition, 1993.
[61] D. Moraetis, D. Efstathiou, F. Stamati et al., "High-frequency monitoring for the identification of hydrological and biogeochemical processes in a Mediterranean river basin," Journal of Hydrology, vol. 389, no. 1-2, pp. 127-136, 2010.

[62] B. Turgut, "Comparison of wheat and safflower cultivation areas in terms of total carbon and some soil properties under semiarid climate conditions," Solid Earth, vol. 6, no. 2, pp. 719-725, 2015.

[63] A. Novara, J. Rühl, T. La Mantia, L. Gristina, S. La Bella, and T. Tuttolomondo, "Litter contribution to soil organic carbon in the processes of agriculture abandon," Solid Earth, vol. 6, no. 2, pp. 425-432, 2015.

[64] M. Muñoz-Rojas, A. Jordán, L. M. Zavala, D. De la Rosa, S. K. Abd-Elmabod, and M. Anaya-Romero, "Impact of land use and land cover changes on organic carbon stocks in mediterranean soils (1956-2007)," Land Degradation and Development, vol. 26, no. 2, pp. 168-179, 2015.

[65] L. L. Roa-Fuentes, C. Martínez-Garza, J. Etchevers, and J. Campo, "Recovery of soil $\mathrm{C}$ and $\mathrm{N}$ in a tropical pasture: passive and active restoration," Land Degradation and Development, vol. 26, no. 3, pp. 201-210, 2015.

[66] J.-M. Harmand, H. Ávila, R. Oliver, L. Saint-André, and E. Dambrine, "The impact of kaolinite and oxi-hydroxides on nitrate adsorption in deep layers of a Costarican Acrisol under coffee cultivation," Geoderma, vol. 158, no. 3-4, pp. 216-224, 2010.

[67] I. E. Odom, "Smectite clay minerals: properties and uses," Philosophical Transactions of the Royal Society of London Series A, vol. 311, no. 1517, pp. 391-409, 1984.

[68] J. Wauters, A. Elsen, A. Cremers, A. V. Konoplev, A. A. Bulgakov, and R. N. J. Comans, "Prediction of solid/liquid distribution coefficients of radiocaesium in soils and sediments. Part one: a simplified procedure for the solid phase characterisation," Applied Geochemistry, vol. 11, no. 4, pp. 589-594, 1996.

[69] G. R. C. Cooper, "Oxidation and toxicity of chromium in ultramafic soils in Zimbabwe," Applied Geochemistry, vol. 17, no. 8, pp. 981-986, 2002.

[70] M. E. Essington, Soil and Water Chemistry, An Integrative Approach, CRC Press, Washington, DC, USA, 2004.

[71] F. Bergaya, G. Lagaly, and M. Vayer, "Cation and anion exchange," in Handbook of Clay Science, Development in Clay Science, F. Bergaya, B. K. G. Theng, and M. Vayer, Eds., pp. 979-1001, Elsevier Science \& Technology, Amsterdam, The Netherlands, 2006.

[72] M. B. McBride, Environmental Chemistry of Soils, Oxford University Press, New York, NY, USA, 1994.

[73] A. D’Annibale, M. Ricci, D. Quaratino, F. Federici, and M. Fenice, "Panus tigrinus efficiently removes phenols, color and organic load from olive-mill wastewater," Research in Microbiology, vol. 155, no. 7, pp. 596-603, 2004. 

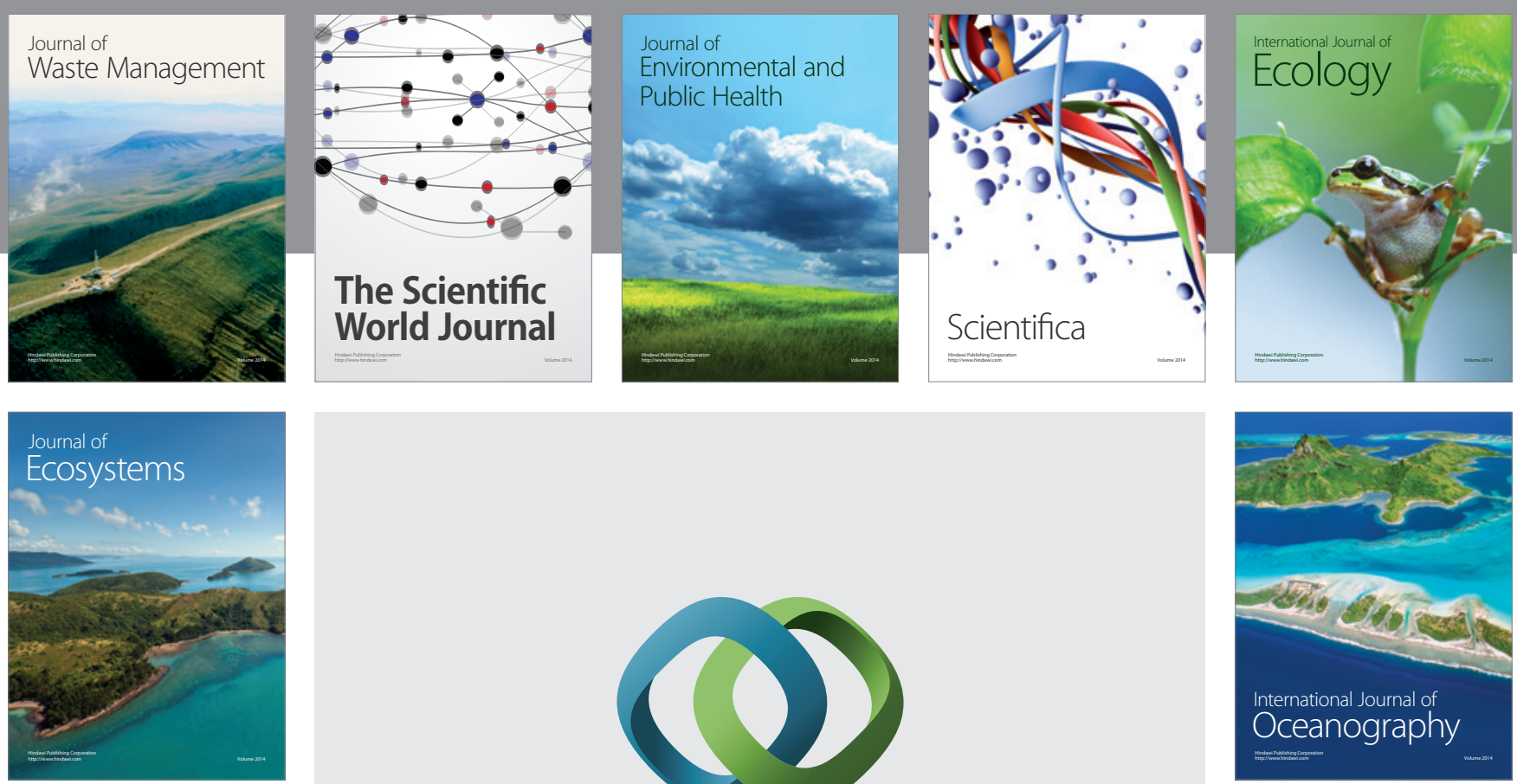

The Scientific World Journal
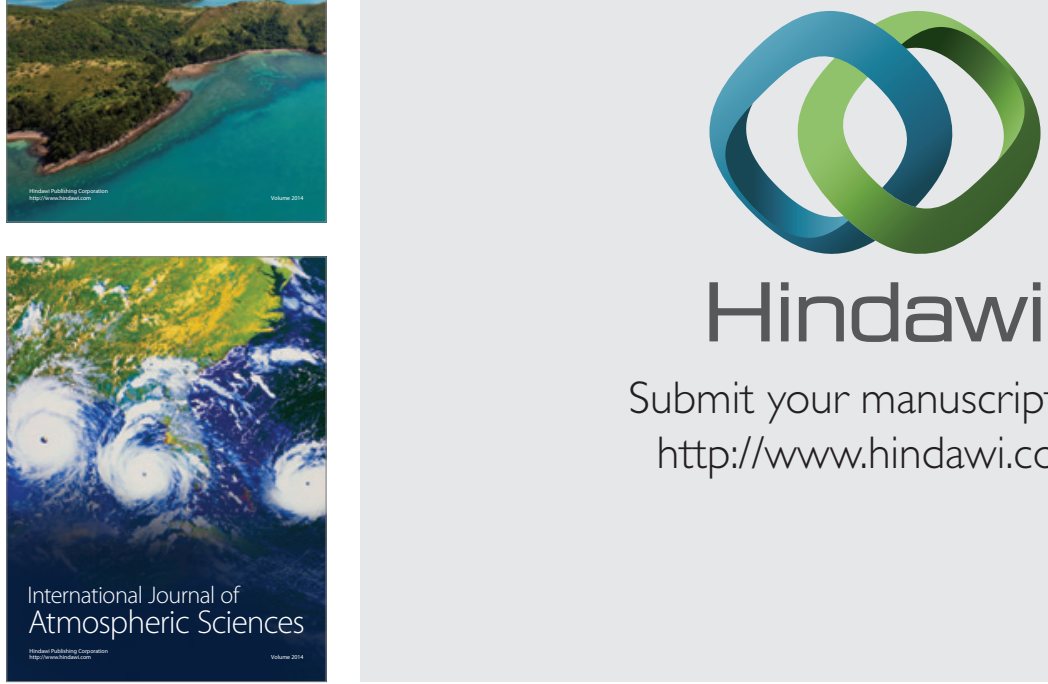

\section{Hindawi}

Submit your manuscripts at

http://www.hindawi.com
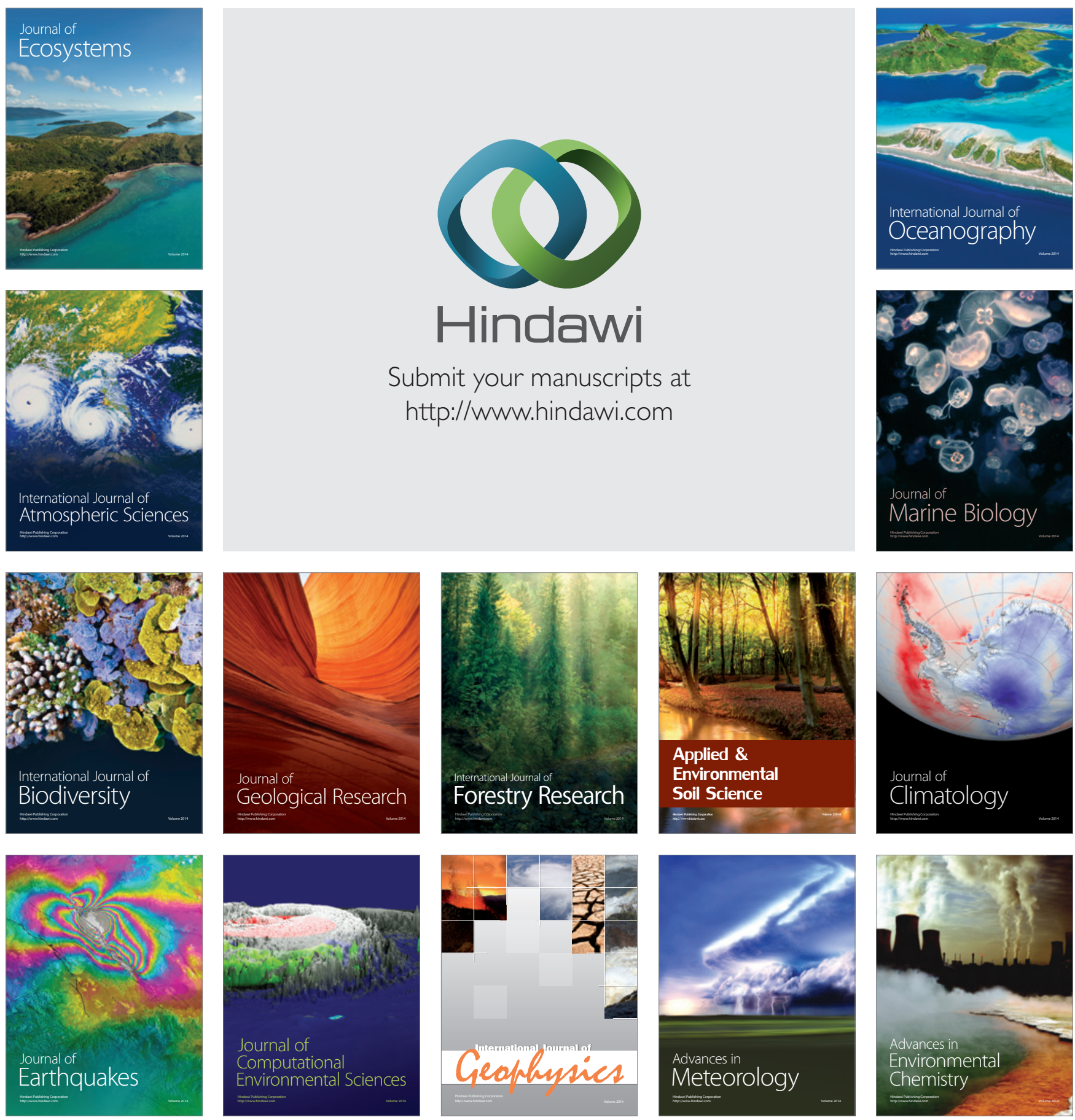